\title{
Arranging A Gamelan Penting Ensemble Through Exploration and Interpretation Process
}

\author{
Pande Made Sukerta I Nyoman Sukerna Ketut Gura Arta Laras \\ Indonesia Institute of the Arts Surakarta
}

The research is financed by Direktorat Riset dan Pengabdian Masyarakat, Kementerian Riset dan Teknologi Badan Riset dan Inovasi Nasional

\section{Abstract}

An ensemble or commonly reffered to as a set of gamelan or barungan (in Bali) was a collection of musical instruments consisting of various types and forms of musical instruments used to present music. The quantity, shapes, and types of instruments used was depended on the ensemble type. Setting up a gamelan ensemble took a long time. gamelan ensemble could not be formed immediately. The musical instruments in it were arranged through evolutionary changes. The type and number of instruments used had been changed with musical or aesthetic considerations, as well as functional developments, and were carried out with enthusiasm. The factors that support the formation of a gamelan ensemble were the needs of the community, the creativity of the artists, and the dynamics of the community. The formation of a gamelan penting ensemble was a step towards creating an ensemble that was musically dominated by penting instruments. The formation of penting gamelan ensemble was carried out through various processes of exploration and interpretation. The exploration here related to the use of other types of instruments other than penting instrument and the size of penting instrument, while the interpretation was related to musical (aesthetic) considerations embodied by the type and shape of the instrument used.

Keywords: Exploration, interpretation, aesthetics, enthusiasm

Publication date:September $30^{\text {th }} 2020$

DOI: $10.7176 / \mathrm{ADS} / 85-03$

\section{Introduction}

Gamelan ensemble or music ensemble or barungan gamelan was a group consisting of various types, forms, and quantity of instruments that presented a piece of music or gending. Each type of instrument used in an ensemble has a different function, for example there were instruments that emphasized more on balungan or bantang gending, or garap, and there were instruments that emphasized more on maintaining rhythm. In general, the duties and functions of the instruments in the Balinese gamelan ensemble or barungan could be divided into six groups, namely the bantang gending instrument group, the pepayasan, the pengramen, the penandan, the pesumulih, and the pemanis instrument group (Sukerta, 2009: 150-193). The six groups of instruments were used in large and medium sized gamelan ensembles, namely ensembles that used many types of instruments such as gamelan gong gede ensemble, gong kebyar, gong luang, angklung don nem, angklung klentangan, semar pegulingan saih lima, and semar pegulingan saih pitu.

The size of the gamelan ensemble depended on the quantity and type of instrument used. The use of instruments in one ensemble ranged from one type of instrument to using various types and quantity of instruments, so that there were ensembles that were "small" and "large". The "small" ensemble used a few types and quantity of instruments, the musicians were also few in quantity. While the "large" ensemble form used a wide variety of instruments and a large quantity of instruments, which meant that there were many players involved. Whether the ensemble was "small" or "large", both of which produced the same musical or aesthetic, as in Balinese musicals, gamelan gender wayang parwa ensemble used one type of instrument consisting of two pieces of instrument gender wayang pengede. The resulting musical composition was very "complete". Likewise, gamelan gong gede ensemble used thirty-nine types of instruments and required sixty musicians.

The use of a complete instrument produced a "complete" composition. The decision to determine the quantity of instruments did not affect the musicality of the composition. This happened because each gamelan group had a different musical anatomy and aesthetic. That was the fact about the phenomenon related to the size of the gamelan ensemble in Bali which was very much determined by the needs of the community, in this case related to the function, aesthetic needs, the creativity of the artists, and the dynamics of the society.

The types of gamelan ensembles in Bali were not born immediately or formed as is witnessed today. I believed that the formation of a gamelan ensemble in Bali went through various processes and required a long processing time. In addition, the process of forming a gamelan ensemble was very costly.

\section{Discussion}

All gamelan ensembles in Bali had undergone a long formation process, because their existence was largely determined by the needs of the community, aesthetic needs, the creativity of the artists, the enthusiasm and 
dynamics of the community.

In Bali there were approximately forty-three types of gamelan ensembles, each of which used a different quantity and different form of instruments. Regarding the formation of a gamelan ensemble, there were two examples of the process of aranging a gamelan ensemble in Bali by going through various processes including the following.

\subsection{Gamelan Gong Kebyar Ensemble}

In Sukerta's book entitled Gong Kebyar Buleleng Perubahan dan Berkelanjutan Tradisi Gong Kebyar (2009) it was stated that gamelan gong kebyar ensemble was formed through various processes, for example changing from the use of seven plates on a gangsa instrument to ten plates (ugal, pemade, and kantil). Changes in the quantity of plates used took a relatively long time. In addition to changes in the use of plates, there were also additional types of instruments used. Initially, gamelan gong kebyar ensemble did not use trompong instrument and giying instrument, but now gamelan gong kebyar ensemble had used both instruments. Likewise, the process of using bende or bebende and kempli instruments in gamelan gong kebyar ensemble. Both types of instruments were used in gamelan gong kebyar ensemble for aesthetic reasons. This meant that gamelan gong kebyar ensemble presented gong gede (lelambat) repertoire which used bebende and kempli instruments. Therefore, all gamelan gong kebyar ensembles now used bebende and kempli types of instruments. Thus, gamelan gong kebyar ensemble now used the following types of instruments: one trompong instrument, three pairs of kIendang (cedugan, gupekan, and plegongan/krumpungan), two giying instruments, four pemade instruments, four kantil instruments, two penyacah instruments, two jublag instruments, two jegogan instruments, one reyong instrument, one ceng-ceng gecek instrument, one kajar instrument, one rebab instrument, several flutes (at least three flutes), some cakep ceng-ceng kopyak (at least three cakep), one kempli instrument, one kenong instrument, one bebende instrument, one kempul instrument, and two bungkul gong (lanang and wadon). On certain occasions, gamelan gong kebyar ensemble sometimes used gender rambat instrument, because gamelan gong kebyar ensemble was used to present plegongan (music for the Plegongan dance).

Other changes that occurred in the gamelan gong kebyar ensemble were the increase in the quantity of pemade instruments and the increasing size of trompong, barangan, and gong instruments (pencon). In the Buleleng area, usually each gamelan gong kebyar group used four pemade instruments. After experiencing a change, each gamelan gong kebyar group now used six to eight pemade instruments. In addition to increasing the size, it also increased the thickness of the tone area used in the trompong, barangan, and gong instruments. The changes that occurred in gamelan gong kebyar ensemble North Balinese style were due to enthusiasm in the competition between groups in playing gong kebyar.

After discussing the formation of the gamelan gong kebyar ensemble above, it could be concluded that the formation of gamelan gong kebyar ensemble by adding the use of the quantity and types of instruments was based on the needs of society, aesthetic needs, the creativity of the artists, enthusiasm, and the dynamics that occur in the community.

\subsection{Gamelan Jegog Ensemble}

considering from its growth, the gamelan jegog ensemble could be said to have undergone three changes as followed. Initially, the gamelan jegog ensemble used the rindik or tingklik type of instrument made of wood or bamboo. Over a long period of time, the types of instruments used in the gamelan jegog ensemble were replaced by large bamboo materials. Even then, the type and number of instruments used were not like today, using fourteen instruments grouped into six types of instruments with details of one jegog instrument group, two undir instrument groups, two celuluk instrument groups, three suir instrument groups, three kancil instrument groups, and three barangan instrument group. The third development of Jegog Gamelan ensemble was the use of various types of instruments, namely ceng-ceng gecek, kendang, flute, and tawa-tawa. Changes in the use of materials, increasing sizes, and the addition of types of instruments in gamelan jegog ensemble were caused by aesthetic needs and functional development. This gamelan ensemble originally presented instrumental repertoire for aesthetic needs, now it was developing to present dance accompaniment repertoire.

Based on my observations, penting instrument could be said to have no place or was not accommodated in an ensemble that did not provide a dominant function to penting instrument, both quantitatively and musically. These observations reveal that there were several forms of gamelan penting ensemble, from small to large ensembles. Observations show that there was not yet an adequate ensemble form. So it was necessary to make a gamelan penting ensemble, a form of offer made to the community and its supporting artists.

Gamelan penting ensemble was one type of Balinese gamelan ensemble which is dominated by penting instrument. This dominance could be seen in the number of penting instruments involved in it, as well as from a musical perspective.

At first, penting instrument was likened to a human being or a person who did not have his own house. He was often adventurous and is often used in other types of gamelan ensembles, so that the musical essence of 
penting instrument could not appear dominant.

My experience when doing research entitled "Penciptaan Ensambel Gamelan Penting" was an example that could be described. During this research activity, I tried to create a gamelan penting ensemble. It turns out that in making it happened, I needed to carry out various processes of exploration and interpretation, especially musical interpretation. Exploration activities in the formation of gamelan penting ensemble were activities related to the use of the types of instruments used in the Gamelan penting ensemble and interpretation activities, especially musicals, were activities related to musical matters. Exploration activities in the formation of gamelan penting ensemble were carried out by constantly trying to use this type of instrument. After finishing using the instrument, then an evaluation was continued which emphasized more on musical evaluation. The experiments carried out in creating gamelan penting ensemble as followed.

a. I played jublag instrument. It turned out that from a musical perspective, the sound of penting instrument did not stand out. Apart from that, the compositions with slendro tunes always sounded like gamelan curclutur somnncitione The evnerimental reculte made me decided not to use jublag instrument music pres below.

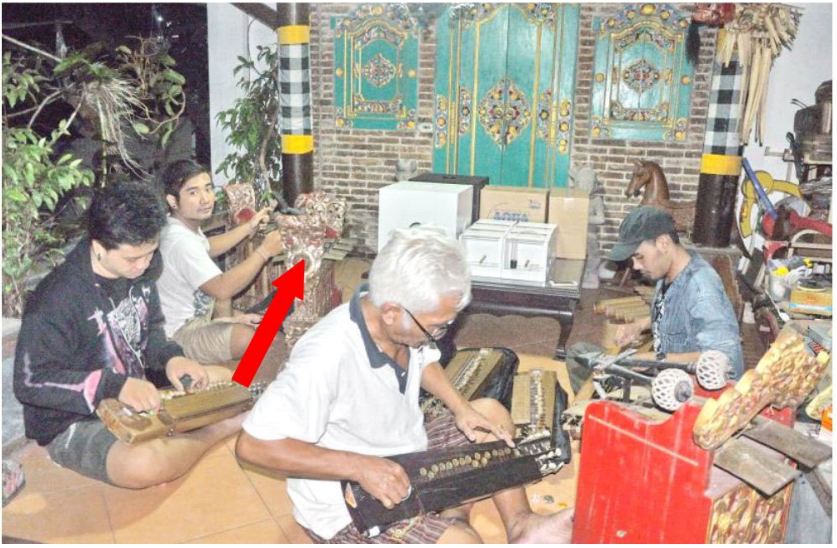
already show the rhytm of the taken during the exploration

Exploration in playing jublag instrument. The arrow indicated jublag instrument

(Doc. Pande Made Sukerta. 2020)

b. The next exploration activity was to use tawa-tawa instrument. In the exploration activities, it was discovered that the musicality of the tawa-tawa instrument sound was too prominent so that it would overpower the sound of penting instrument, while the desired design in this ensemble was the prominence of penting instrument. Based on the results of the musical evaluation, tawa-tawa instrument was replaced with ketimbung instrument. Ketimbung instrument was an instrument that has a plateshaped sound source made of bamboo. The involvement of ketimbung instrument in processing the sound of penting instrument was musically very supportive. For more details, see the pictures of tawatawa and ketimbung instruments during the exploration activities below.

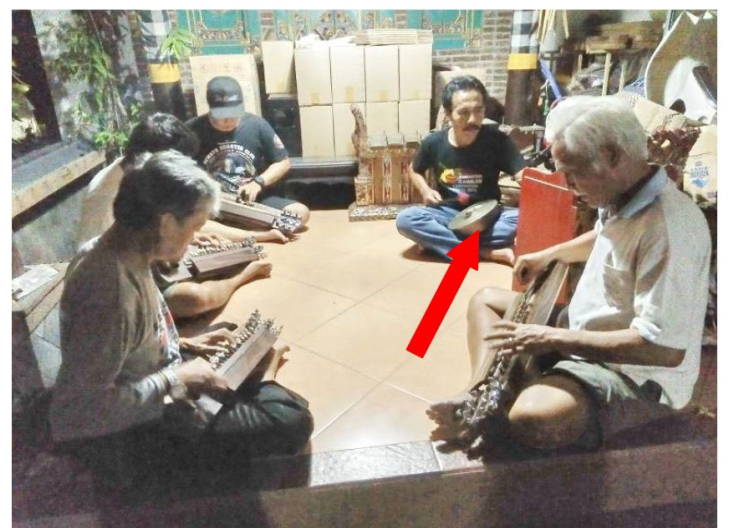

Exploration in playing tawa-tawa instrument. The arrow indicated tawa-tawa instrument (Doc. Pande Made Sukerta. 2020) 


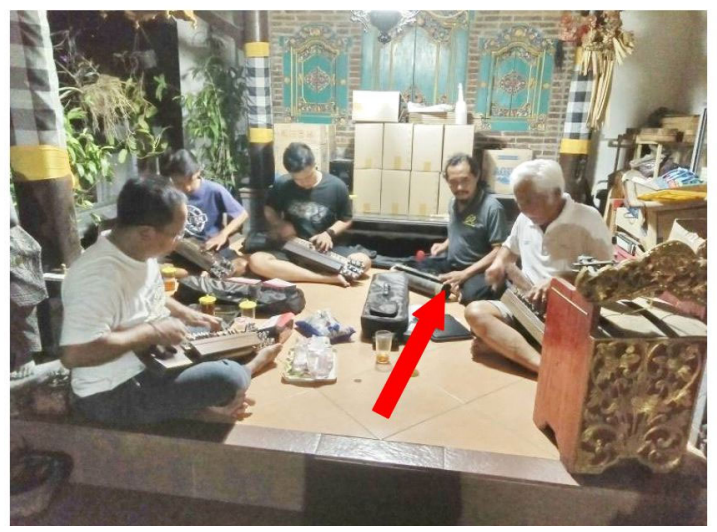

Exploration in playing ketimbung instrument. The arrow indicated ketimbung instrument

(Doc. Pande Made Sukerta, 2020)

c. I tried to use a gentorag instrument. As a result, from a musical perspective, gentorag did not match the sound of penting instrument, because both instruments had sharp sounds. So gentorag instrument was not suitable to be added to gamelan penting ensemble. Gentorag instrument was a collection of bells consisting of three sizes (large, medium, and small) bells made of brass which was attached by hanging on a wooden handle. The difference in the size of each of the three bell groups was relatively small. These bells made a sound by shaking them, so that each bell that was attached would jiggle and produce sound.

d. I tried to use titir flute instrument, in hoped of extending the sound produced by penting instrument. From a musical perspective, the use of titir flute instrument provided many positive values. So I continued to form gamelan penting ensemble by including titir flute instrument. For more details, pay attention to the picture of titir flute instrument taken during the exploration activity below.

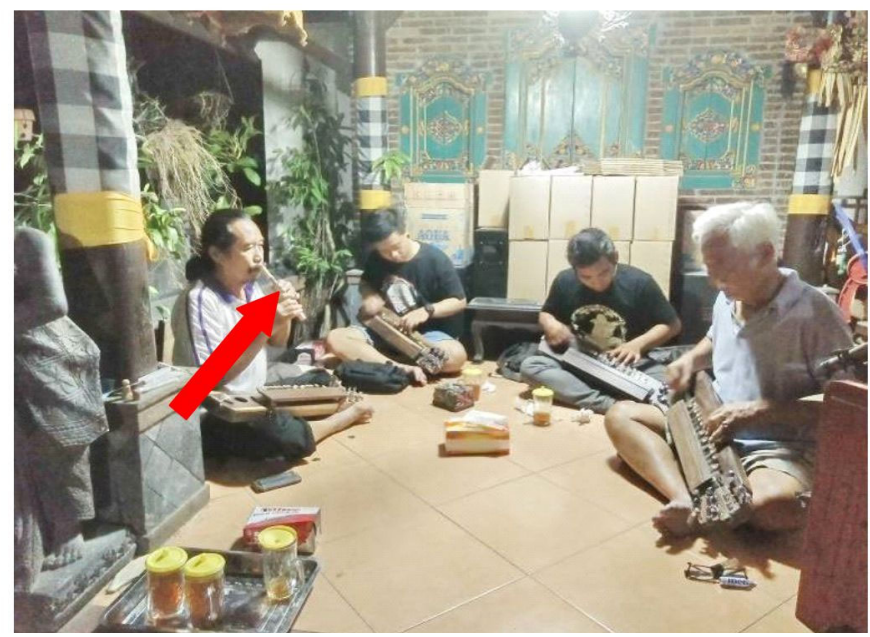

Exploration in playing titir flute instrument. The arrow indicated titir flute instrument (Doc. Pande Made Sukerta, 2020)

\section{Conclusion}

Based on the results of the above discussion, it could be concluded that the creation or formation of a gamelan ensemble, especially gamelan penting ensemble, did not only involve or use the type and quantity of instruments desired or owned by the creator, but must carry out exploration activities in selecting and using the type of instrument. Next was the interpretation activity using musical considerations. Thus the formation of gamelan ensemble, especially gamelan penting ensemble, was successful after going through a process that involved several stages. The selection of the types and forms of instruments used in gamelan ensemble was aimed at building musical anatomy/aesthetics.

\section{References}

Aryasa, I W.M. 1976/1977. Perkembangan Seni Karawitan Bali. Denpasar: Laporan Proyek Sasana Budaya Bali. Balyson. 1934. "Gong-Gede (Kebijar) Samboengan Bhawanagara No. 11-12", dalam Bhawanagara, Soerat boelanan oentoek memperhatikan peradaban Bali, Juni, Tahoen III.

Balyson. 1934. Gong-Gede (Kebijar). Samboengan Bhawanagara No. 11-12. Dalam Bhawanagara Soerat 
boelanan oentoek memperhatikan peradaban Bali. Juni, Tahoen III.

1934. "Gending Gong", dalam Bhawanagara, Soerat boelanan oentoek memperhatikan peradaban Bali. No. 4-5 September-Oktober, Tahoen IV.

Bandem, I Made. 2013. Gamelan Bali Di Atas Panggung Sejarah. Denpasar : BP STIKOM BALI.

Hastanto, Sri. 1997/1998. "Dari Krumpyung ke Calung Sebuah Peristiwa Genetika Musikal". Laporan Penelitian Mandiri. Surakarta : Sekolah Tinggi Seni Indonesia (STSI).

Rai S., I Wayan, dkk. 1999. "Keragaman Laras (Tuning System) Gamelan Gong Kebyar”. Denpasar : Sekolah Tinggi Seni Indonesia.

Sukerna, I Nyoman. 2006, "Gender Wayang: Barungan Gamelan Bali Kelompok Tua". Vol.4 No.1 Jurnal Dewaruci, Surakarta : Pascasarjana STSI Surakarta. 2008. "Musikalitas Gamelan Jegog Bali”. Jurnal DEWARUCI, Surakarta : Pascasarjana ISI Surakarta.

Sukerta, Pande Made. 2001. "Gong Kebyar Gaya Buleleng Cerminan Budaya Masyarakat Bali Utara” (Tesis). Denpasar : Program Studi Kajian Budaya Program Pascasarjana, Universitas Udayana Denpasar (UNUD). . 2001. Jenis-jenis Tungguhan Gamelan Bali, ISBN : 979-950687-3-2, Penerbit : Proyek Pengembangan Media Kebudayaan, Direktorat Jenderal Kebudayaan, Departemen Pendidikan Nasional Republik Indonesia. 2009. Gong Kebyar Buleleng Perubahan dan Keberlanjutan Tradisi Gong Kebyar, Penerbit : Program Pascasarjana bekerjasama dengan ISI Press Surakarta. 2010. Tetabuhan Karawitan Bali I, Surakarta : ISI Press Solo. dan I Nyoman Sukerna. 2018. Buku Ajar Pembuatan Instrumen Blablabla. Surakarta : ISI Press. I Nyoman Sukerna, dan Ketut Gura Arta Laras. 2019. Cara Memainkan Instrumen Blablabla. Surakarta : ISI Press.

Supanggah, R. 2003. "Keragaman adalah Berkah". Makalah ini disampaikan pada Serial Seminar Internasional Seni Pertunjukan Indonesia Seri III 2002-2004 bertema Diversitas dan Pluralitas Kebudayaan dan Seni Pertunjukan” 21 dan 23 Juli 2003. Surakarta : Sekolah Tinggi Seni Indonesia (STSI). 